https://doi.org/10.18485/iipe_postkovid.2021.ch1

\title{
NEDOSTACI PRISTUPA PANDEMIJI KOVID 19 KAO BEZBEDNOSNOJ PRETNJI
}

\author{
Miroslav STEVANOVIĆ ${ }^{1}$ \\ Dragan ĐURĐEVIĆ
}

\begin{abstract}
Apstrakt: Virus SARS KoV 2, za koji nije postojala vakcina, stvorio je rizik koji je uzrokovao globalnu pretnju za individualno i javno zdravlje. Osim toga, pandemija Kovid 19 generisala je ekonomske, socijalne i političke izazove za države. Reakcija država u suočavanju sa ovim izazovima, rizicima i pretnjama je, najopštije posmatrano, predstavljala pokušaj nametanja individualnog ponašanja i aktiviranje vanrednih mera radi zaštite zajedničkog interesa, kao vrednosti. lako je cilj reakcije bio zaštita lične bezbednosti i stabilnosti političkih zajednica, primena mera se suočila sa značajnom rezervom javnosti. U ovom članku predstavljamo analizu pristupa suprotstavljanju pandemiji kao bezbednosnoj pretnji i virusu kao „nevidljivom neprijatelju“. Da bismo utvrdili potencijalne probleme za delotvornost reakcije usled takvog pristupa, posmatrali smo normativne i vrednosne neusklađenosti između nacionalne odgovornosti i međunarodnog okvira u suočavanju sa globalnom zdravstvenom pretnjom. Rezultati pokazuju da je bezbednosni pristup nužno vodio tome da delotvornost mera i odluka zavisi više od prihvatanja diskursa o ozbiljnosti pretnje, a manje od poverenja u njihovu svrsishodnost. To ukazuje na funkcionalni nedostatak pristupa, u smislu da odstupa od osnovnog načela u zaštiti bezbednosti - društvenog prihvatanja vrednosti, što je, uprkos pretnji i zaštićenim vrednostima, dovelo do neusklađenosti između odlučilaca i stanovništva. Analiza pokazuje dva uzroka nedelotvornosti vezana za bezbednosni pristup suočavanja sa pandemijom: sprovođenje transnacionalnih preporuka suočava se sa problemom nedostatka demokratskog legitimiteta, a oslanjanje na ubeđivanje, bez prethodne naučne izvesnosti, podriva poverenje javnosti u odluke.
\end{abstract}

Ključne reči: javno dobro, spremnost, osnaživanje ljudi, globalni odgovor, naučna izvesnost, društvene mreže.

\footnotetext{
${ }^{1}$ Vanredni profesor, Pravni fakultet Univerziteta Megatrend, Beograd, e-mail: mstevanovic@ megatrend.edu.rs

${ }^{2}$ Vanredni profesor, Pravni fakultet Univerziteta Megatrend, Beograd, e-mail: ddjurdjevic@ megatrend.edu.rs
} 


\section{Uvod}

U slučaju izbijanja zaraze novim sojem virusa na koji većina ljudi nema imunitet i koji se lako širi i izaziva epidemije širom sveta, a odlikuju ga teška oboljenja i smrtnost, Svetska zdravstvena organizacija (SZO) može da proglasi pandemiju. ${ }^{3}$ Zdravstvene posledice i prateća negativna društvena, ekonomska i politička dejstava pandemiji daju potencijal generisanja pretnji za političke zajednice. Sprečavanje i suzbijanje pandemije u Međunarodnom zdravstvenom pravilniku (International Health Regulations - IHR) utvrđeno je kao predmet međunarodne brige. Ovim međunarodnim pravnim okvirom, države članice SZO su se obavezale da razvijaju svoje normativne i materijalne kapacitete u pripremljenosti, odgovoru, resursima, kadrovima i laboratorijama za slučaj takve pojave. Logika pristupa suočavanju sa pandemijom uspostavljenog kroz IHR, koja prvenstveno predstavlja globalni zdravstveni rizik, podudara se sa pristupom bezbednosnim izazovima, u smislu da ima elemente zaštite globalne bezbednosti utemeljene na postojanju odgovarajućih kapaciteta država članica.

Okvir IHR uspostavlja vezu između lične bezbednosti, nacionalne i međunarodne bezbednosti kroz teorijske koncepte poznate kao „ljudska bezbednost “ $i$ „odgovorni suverenitet". Primena ovih koncepata povezana je sa sposobnošću države da obezbedi sigurnost stanovništva, koja povratno legitimiše njen autoritet na nacionalnom i međunarodnom nivou. Ovo nameće dva vrednosna pitanja. Prvo proističe iz činjenice da su države racionalni, interesno orijentisani subjekti koji, kao takvi, posvećuju resurse za ljudsku bezbednost kada im to omogućava neku neposrednu korist. To otvara dilemu da li je okvir IHR prvenstveno u interesu zaštite individualne bezbednosti ili u interesu stabilnosti država, pre svega razvijenih, od ekonomskih i drugih negativnih dejstava pandemije. Drugo vrednosno pitanje proizlazi iz sekuritizacije zdravlja na globalnom nivou, bez opšteg zdravstvenog osiguranja. Ovo u prvi plan dovodi interese izvršnih vlasti i marginalizuje ciljeve javnog zdravlja na nivo političkih narativa.

\footnotetext{
3 "Prevention and control of influenza pandemics and annual epidemics", WHO, 28 May 2003, WHO doc. WHA56.19, Agenda item 14.14, Preamble.

${ }^{4}$ WHO, Key Messages - Conflict of Interest Issues, World Health Organization, 10 Janary 2010. Internet: https://www.who.int/vietnam/news/detail/10-01-2010-who-key-messages --conflict-of-interest-issues, 05/02/2021.
} 
Opis pandemije SZO nikada nije usvojen kao deo formalne definicije. ${ }^{4}$ Stoga bi ga trebalo posmatrati u širem kontekstu. Generalna skupština Ujedinjenih nacija pozvala je države da prepoznaju veze između unapređenja opšte zdravstvene zaštite i spoljnopolitičkih pitanja, poput društvene dimenzije globalizacije, stabilnosti, inkluzivnog i pravičnog rasta i održivog razvoja, održivosti nacionalnih finansijskih mehanizama i značaja opšte zdravstvene zaštite. ${ }^{5}$ Ovakav kontekst implicira vezu između opštosti zdravstvenih pretnji i bezbednosti, a takođe ukazuje na saglasnost o zavisnosti zdravstvene bezbednosti od primene međunarodnih zdravstvenih propisa, opštih i pravičnih zdravstvenih sistema.

Odnos pandemije i bezbednosti obuhvata tri ključne postavke. Prvo, povezivanje obaveza zdravstvene politike sa bezbednošću može podići nivo prioriteta i dati rezultate. Drugo, zdravstvena bezbednost ne odvaja politiku od zdravstvenih kriza, već naglašava globalni i nacionalni interes za spremnost i reagovanje na pandemiju, te doprinosi podizanju cilja opšte zdravstvene bezbednosti. Treće, usklađenost sa međunarodnim zdravstvenim propisima mora biti sprovođena na regionalnom nivou i podržana od globalnih institucija.

Pristup koji deli grip na pandemijski i sezonski nije usredsređen na uzrok virus ili drugi patogen. On je vezan za ispoljavanje primarne pretnje, tj. da se ozbiljnost i dejstvo javljaju duž spektra, bez obzira na razmere štete. Teorijski posmatrano, reakcije na pretnju, umesto da ih projektuju unapred zadate kategorije, trebalo bi da su vezane za prirodu pretnje. U slučaju odgovora na pandemiju, već se ističu međunarodni pozivi za pojednostavljenje faze pandemije i za planove koji „ističu pristup zasnovan na riziku kako bi se omogućio fleksibilniji odgovor na različite scenarije". ${ }^{6}$ Međutim, reakcija u krizi Kovid 19 je, čini se, bila vođena nastojanjem administracija da bude suzdržan, a ne sa aspekta najgoreg scenarija.

Krizu Kovid 19 pokrenuli su globalno širenje i posledice zaraze novim virusom SARS-KoV 2, za koji nije postojala vakcina ni terapija. Izazov za javne vlasti bio je da se obuzda širenje zaraze i obezbedi javno zdravlje, kao zajednički interes

\footnotetext{
5 "Global Health and Foreign Policy", UN General Assembly, 12 December 2012, UN doc. A/67/L.36, Art. 3.

6 "Report of the Review Committee on the Functioning of the International Health Regulations (2005) in relation to Pandemic (H1N1) 2009", WHO, 5 May 2011, WHO doc. WHA64/10, Annex 1, Rec. 7.
} 
političkih zajednica. Upravljanje javnim poslovima standardizovano je u doktrini međunarodnog prava kao dobro upravljanje, koje teži da unapredi poželjne atribute vladavine, poput vladavine prava, transparentnosti, odgovornosti, kontrole korupcije, inkluzivnosti. ${ }^{7}$ Mnoge međunarodne organizacije i nadnacionalna tela prihvataju koncept upravljanja koji obuhvata korišćenje pravila i normi i uspostavljanja nadležnosti, uloga, praksi i ograničenja radi usmeravanja ponašanja ka postizanju željenog kolektivnog ishoda. ${ }^{8}$ Ovaj normativni razvoj, prema nekim teoretičarima, često je u pozadini opterećen agendom da nameće model države. ${ }^{9}$

U ovom radu posmatramo nivo delotvorne primene standarda dobre vladavine tokom krize Kovid 19. Sa prvom godinom pandemije u mnogim državama mere vlada izazivaju masovne proteste. Mediji i sajber prostor su puni različitih nalaza i razmišljanja koja izazivaju sumnju u niz informacija koje nacionalne vlasti i međunarodna tela prenose javnosti. Revolt je otišao dotle da u javnom diskursu neki vladavinu tokom pandemije etiketiraju kao „korona tiranija“.

Većina vlada nije bila spremna za hitan zdravstveni problem globalnih razmera i, bez unapred pripremljenih odgovarajućih strategija i kapaciteta, oklevala je u reakciji. Pandemija Kovid 19 stvara pretnju po ljudsku bezbednost, ne samo povećanim nivoom smrtnosti, već i negativnim dejstvom na ekonomsku, socijalnu i političku strukturu društava. Zbog mnogih činilaca, među kojima su hiper globalizacija i rastuća međusobna povezanost, zarazne bolesti se brže šire svetom, te postaju složenija pretnja.

Postojeća doktrina bezbednosti označila je pandemiju Kovid 19 kao pretnju nacionalnoj bezbednosti. Ovaj koncept podrazumeva da se pretnja pandemije po zdravlje uklapa u tradicionalnu ulogu i funkcije bezbednosnih i obaveštajnih sistema, ali zanemaruje nedostatak unutrašnje sposobnosti tih sistema za odgovarajuće reagovanje. U tom smislu, politički okvir suočavanja sa ovom pandemijom, koji se oslanjao na koncept da se radi o pitanju nacionalne

\footnotetext{
${ }^{7}$ Miroslav Stevanović \& Dragan Đurđević, „Konceptualizacija pojma represivni režim u međunarodnom javnom pravu", Zbornik radova Pravnog fakulteta u Nišu, vol. 57, no. 80, 2018, str. 111-112.

${ }^{8}$ The Public Sector Committee, Governance in the Public Sector: A Governing Body Perspective, The International Federation of Accountants, New York, 2001, pp. 57-58.

${ }^{9}$ Merilee Grindle, Going Local: Decentralization, Democratization, and the Promise of Good Governance, Princeton University Press, Princeton/Oxford, 2009, p. 170.
} 
bezbednosti, imao je nedostatke u primeni tog koncepta u političkoj i administrativnoj praksi. ${ }^{10}$

Dobijeni rezultati trebalo bi da omoguće pokazatelje o poštovanju opšteprihvaćenih vrednosti u odnosu između građana i javnih vlasti. Značaj rezultata je u tome što ukazuju na nivo odgovornosti i egocentričnosti izvršne vlasti, pod okriljem delovanja za opšte dobro.

\section{Metod}

Napori na suzbijanju masovnih zdravstvenih posledica Kovid 19, kao socijalne, ekonomske i političke posledice, pokazali su važnost spremnosti političke zajednice za takve pojave. U tom kontekstu, pitanje leka ili vakcine je od značaja samo indirektno, jer se očekuje da međunarodne i nacionalne vlasti ispolje sposobnost da reaguju na situaciju koja nije istorijski nova. Problem efikasnosti dominantnog pristupa u smanjenju zdravstvene štete i zaštiti društva i pojedinaca uočava se u posebnim ciljevima pripremljenosti i odgovora/reakcije.

Kako bi analizirali primenu standarda dobrog upravljanja tokom krize Kovid 19, prvo smo posmatrali funkcionalni aspekt nacionalne organizacije $u$ upravljanju interesima javnog zdravlja, posebno odgovornost $\mathrm{u}$ tom procesu i međunarodna pravila koja predstavljaju okvir za nacionalno upravljanje. Zatim smo razmotrili praktične mere preduzete radi upravljanja javnim zdravstvenim i društvenim i ekonomskim izazovima koje generiše pandemija, pri čemu smo se usredsredili na normativna odstupanja od standarda dobrog upravljanja.

Osnovni istraživački cilj bio je utvrditi razlog za kontroverzna gledišta u vezi sa nacionalnim pristupom krizi. S obzirom na to da još uvek nije moguće proceniti tačnost informacija o virusu i simptomima, efikasnosti usvojenih pravila, kao ni mera i posledica primenjenog administrativnog pristupa, rad je ograničen na strukturno-funkcionalnu analizu opšteg pristupa upravljanju ovom krizom.

Rad uzima u obzir međunarodni činilac u upravljanju krizom Kovid 19. Naime, iako se upravljanje prvenstveno odnosi na izabrana i imenovana tela koja imaju

\footnotetext{
${ }^{10}$ Detaljnije: Patrick Walsh, Building a Better Pandemic and Health Security Intelligence Response in Australia, Centre for International Governance Innovation, August 242020. Internet: https://www.cigionline.org/articles/building-better-pandemic-and-healthsecurity-intelligence-response-australia, 05/02/2021.
} 
odgovornost prema građanima, ono je tokom pandemije bilo pod značajnim uticajem međunarodnih mehanizama i nadnacionalne prirode same pretnje.

Rezultati posmatranja uloga i nadležnosti su dalje analizirani sa aspekta spremnosti političke zajednice za delotvorno reagovanje $u$ anticipativnom sistemskom razvoju akcionih planova za nepredviđene događaje, kao i za organizaciona prilagođavanja u skladu sa mogućim pretnjama i kapacitetima za reagovanje.

\section{Normativni okvir pristupa pandemiji Kovid 19}

\section{Odgovornost država}

Odgovornost za pripremljenost i odgovor na pandemiju je na državama. Od njih se očekuje da blagovremeno obezbede najmanje sledeće: (a) telo ovlašćeno za koordinaciju pripremljenosti i reagovanja; (b) pravila i planove za optimalnu pripremljenost i inicijalni odgovor; (c) resurse i njihovu raspodelu prema prioritetima za postizanje ciljeva pripremljenosti; (d) kapacitete za mere odgovora u slučaju pandemije; i (e) postupak saradnje sa drugim državama u slučaju zaraze sa pandemijskim potencijalom. U okviru ove odgovornosti, nacionalni ustavi predviđaju vodeću ulogu izvršne vlasti, na kojoj je da elemente pripremljenosti i odgovora normativno predvidi i institucionalizuje.

Mere pripremljenosti i odgovora na pandemiju su u delokrugu zdravstvene administracije i zdravstvenih službi (sektor zdravstva). Sektor zdravstva obezbeđuje stručnost, standarde svesti o riziku, moguće pretnje zdravlju i odgovarajuće akcije. U tom okviru, od zdravstvenog sektora se očekuje: (a) pouzdane informacije o riziku, ozbiljnosti i širenju moguće masovne zaraze i o delotvornim protokolima i merama tokom takve pojave; (b) davanje prioriteta i pružanje zdravstvene zaštite tokom epidemije/pandemije; (c) naučno predviđanje postupaka i mera potrebnih za suzbijanje širenja zaraze; i (d) definisane procedure za zaštitu i podršku zdravstvenom osoblju i sistemu.

Pravovremena pripremljenost treba da omogući organizovano funkcionisanje važnih sistema i minimizovanje negativnih dejstava pandemije na proizvodnju i distribuciju osnovnih roba i usluga, kao i potencijalnih ekonomskih poremećaja. Mogući ekonomski i posledični društveni rizici generišu pretnju stabilnosti zajednice, zbog čega planiranje suzbijanja uticaja pandemije treba da ima u vidu kontinuitet poslovanja i osnovnih aktivnosti. $U$ cilju pripreme 
za moguće negativne uticaje pandemije na društvo, nezdravstveni sektori trebalo bi da preduzmu: definisanje politika kontinuiteta; analiziranje rizika za privredne subjekte, osnovne usluge, obrazovanje i organizacije; utvrđivanje planova pripremljenosti; razvoj sposobnosti reagovanja; resurse za zaštitu zaposlenih i kupaca i doprinos pripremljenosti i odgovoru.

Činilac smanjenja ozbiljnosti dejstva pandemije je i podrška društva javnom zdravlju, kao opštem dobru, odnosno učešće individua i grupa u njegovoj zaštiti. Podrška antipandemijskim merama se svodi pre svega na individualno poštovanje uvedenih mera i ponašanja. Takođe, pojedinci mogu učestvovati u pružanju dobrovoljne pomoći. U pomoć pripremljenosti i odgovoru na pandemiju trebalo bi da se uključuju i organizacije civilnog društva, koje su često u dobroj poziciji za podizanje svesti, informisanje, pružanje usluga i vezu sa državnim institucijama, a nekad i da povećaju napore u drugim oblastima. ${ }^{11}$

\section{Odgovornost na međunarodnom nivou}

Zaraza virusom SARS-KoV-2 ispoljava se simptomima nalik gripu, te je borba protiv njene pandemije u okviru mandata SZO. Ona državama članicama treba da obezbedi: (a) smernice i tehničku podršku za suočavanje sa pandemijom; ${ }^{12}$ (b) jačanje pripremljenosti i odgovora na pandemiju; ${ }^{13} \mathrm{i}$ (c) razmenu virusa gripa i pristup vakcinama i drugim korisnostima. ${ }^{14}$

Države članice SZO su, u okrilju ove organizacije, usvojile IHR. U skladu sa ovim pravno obavezujućim instrumentom, saradnja organizacije sa državama članicama odvija se kroz: (a) mehanizam koordinacije, (b) određivanje faza pandemije, (c) prelazak na proizvodnju vakcine, (d) akciju brzog suzbijanja i ( e) pružanje ranih procena težine pandemije. U slučaju zdravstvenih rizika koji se

\footnotetext{
${ }^{11}$ WHO, Pandemic Influenza Preparedness and Response a WHO Guidance Document, World Health Organization, Geneva, 2009, p. 10.

12 "Prevention and control of influenza pandemics and annual epidemics", WHO, 28 May 2003, WHO doc. WHA56/19, Art. 2.

13 "Strengthening pandemic-influenza preparedness and response", WHO, 13 May 2005, WHO doc. WHA58.5, Art. 2.

14 "Pandemic influenza preparedness: Sharing of influenza viruses and access to vaccines and other benefits", WHO, 24 May 2011, WHO doc. WHA64/8, Art. 4.
} 
mogu proširiti između država, SZO obezbeđuje međunarodni pravni okvir za sprečavanje, kontrolu ili odgovor na rizike javnog zdravlja. ${ }^{15}$

U skladu sa članovima 6 i 16 IHR, države članice SZO imaju obavezu da obaveste organizaciju o slučajevima ili događajima rizika po javno zdravlje na njihovoj teritoriji, uključujući o „gripu izazvanim novim sojem“. Aneks 2 IHR predviđa da to obaveštavanje mora biti u roku od 24 sata od procene donete $u$ skladu sa definicijom slučaja koju je za ovu svrhu utvrdila SZO. Dalja obaveza države je da prenese detaljne informacije vezane za događaj rizika po javno zdravlje, uključujući definicije slučajeva, laboratorijske rezultate, izvor i vrstu rizika, broj slučajeva i smrtnih slučajeva, uslove koji utiču na širenje zaraze i preduzete javnozdravstvene intervencije. Članice SZO imaju obavezu da prijave i dokaze o ozbiljnim rizicima po javno zdravlje u drugim državama. U skladu sa članom 9 IHR, SZO je ovlašćena da prikuplja izveštaje o potencijalno ozbiljnim međunarodnim rizicima po javno zdravlje i iz nezvaničnih izvora.

U slučaju pandemije, nacionalno upravljanje je, u normativnom pogledu, podvrgnuto bar standardizaciji na međunarodnom nivou. $U$ skladu sa članovima 5.1, 13.1 i Aneksom 1 IHR, države imaju obavezu da razvijaju i izveštavaju o kapacitetima svog javnog zdravstva za otkrivanje, procenu i reagovanje na događaje, kao i da se bave rizikom međunarodnog širenja bolesti preko luka, aerodroma i kopnenih prelaza. Nacionalni odgovor u slučaju potencijalne pandemije i povezanog rizika za javno zdravlje uključuje definisane procedure dobijanja informacija od dolazećih sredstava prevoza i putnika. Korišćenje medicinskih ili javnih zdravstvenih intervencija podleže zahtevima predviđenim u članovima 23, 32, 37-8 i Aneksima 8-9 IHR, prvenstveno vezano za ljudska prava, kao što je prethodni informisani pristanak za preglede, profilaksu ili mere, osim ako okolnosti ne zahtevaju drugačije. SZO, prema članovima 12, 15, 17-18, 48 -49 sprovodi nadzor javnog zdravlja, pruža podršku državama i koordinira međunarodni odgovor na međunarodne rizike po javno zdravlje.

Neposredni napori na suzbijanju pandemijskog gripa ostaju u nadležnosti država. Vrednosno posmatrano, početno obuzdavanje pandemije predstavlja vanrednu akciju protiv pretnje javnom zdravlju. Ono, stoga, prevazilazi same mere odgovora i kontrole bolesti. SZO je izdala smernice za brzo obuzdavanje pandemije, koje definišu procedure u planiranju, obezbeđivanju resursa i

15 "International Health Regulations", WHO, 23 May 2005, 2509 U.N.T.S. 79, Art. 3. 
organizacione aspekte, kao osnov za nacionalne planove. ${ }^{16}$ Kada vlasti države razmatraju operaciju ograničavanja SZO će pružiti savete i podršku u upravljačkim i tehničkim aspektima, kao i u koordinaciji i primeni međunarodnih odgovora. U pogledu pristupa i u operacijama neposrednog ograničavanja vlasti država članica rade zajedno sa SZO.

Nivo zadiranja u nacionalni odgovor zavisi delom od procene težine pandemije. SZO daje procene kako bi se pomoglo vlastima država da odluče o sprovođenju potencijalno ometajućih mera ublažavanja; davanju prioriteta medicinskim intervencijama; upravljanju zdravstvenom zaštitom i obaveštavanju javnosti. Prema Aneksu 4 instrumenta „Ljudska infekcija pandemijskim (H1N1) 2009 virusom: ažurirane privremene smernice SZO o globalnom nadzoru", SZO zasniva procenu težine pandemije prvenstveno na dejstvima na zdravlje. U tom kontekstu, akcije država trebalo bi, u skladu sa delom 3.2.5. pomenutog uputstva SZO „Spremnost i odgovor na pandemijski grip“, da budu povezane sa procenom ozbiljnosti na globalnom nivou. Stoga, nacionalni odgovor ne odražava nužno specifičnu situaciju na terenu.

\section{Pristup Evropske unije}

U kontekstu međunarodne odgovornosti, za evropske države je od značaja i pristup Evropske unije (EU) pandemiji Kovid 19. U martu 2020. godine, lideri EU su kao prioritet u zajedničkom odgovoru organizacije usaglasili četiri oblasti: (1) ograničavanje širenja virusa, (2) obezbeđivanje medicinske opreme; (3) unapređivanje istraživanja za lečenje i vakcinu i (4) podrška radnim mestima, preduzećima i privredi. ${ }^{17}$

U aprilu 2020. godine, Evropska komisija i Visoki predstavnik za spoljnu politiku i bezbednost predstavili su Planove odgovora EU protiv pandemije Kovid 19. Za razliku od pomenutog zajedničkog odgovora, koji je nagoveštavao

\footnotetext{
${ }^{16}$ WHO, Interim Protocol: Rapid Operations to Contain the Initial Emergence of Pandemic Influenza, World Health Organisation, Geneva, 2007, p. 2.

${ }^{17}$ The European Council, Conclusions by the President of the European Council following the video conference on COVID-19, The European Council, 10 March 2020. Internet: https://www.consilium.europa.eu/en/press/press-releases/2020/03/10/statement-bythe-president-of-the-european-council-following-the-video-conference-on-covid-19/, 05/02/2021.
} 
primenu načela isključive i podeljene nadležnosti ove regionalne organizacije u odgovoru na krizu Kovid 19, planove odgovora je pratio diskurs o reakciji EU kao delu šireg odgovora. $U$ tom smislu su ukazivale izjave za javnost najviših funkcionera Evropske komisije:

- Predsednica Evropske komisije: „Virus ne poznaje granice. Za ovaj globalni izazov potrebna je snažna međunarodna saradnja..."

- Visoki predstavnik EU za zajedničku spoljnu i bezbednosnu politiku: „Saradnja i zajednički napori na međunarodnom nivou i multilateralna rešenja su put ka napred..."

- Komesarka za međunarodna partnerstva: „Moramo da sarađujemo kako bismo izašli na kraj sa zajedničkim izazovima."

- Komesar za susedsku politiku i pregovore o proširenju je poručio: „Kao deo globalnog odgovora na pandemiju korona virusa,... možemo uspeti samo zajedno". ${ }^{18}$

Zajednička akcija EU bila je usmerena na suočavanje sa neposrednom zdravstvenom krizom i humanitarnim potrebama, jačanje zdravstva, sistema za snabdevanje vodom i sanitarnih sistema partnerskih država, kao i njihovih kapaciteta za istraživanje i spremnosti za rešavanje pandemije i ublažavanje njenih negativnih društveno-ekonomskih uticaja. Za tu akciju, EU je prihvatila pristup koordiniranog multilateralnog odgovora, u partnerstvu sa UN, međunarodnim finansijskim institucijama, kao i G7 i G20. ${ }^{19}$

Evropska unija oformila je Tim Evropa, koji kombinuje resurse EU, država članica i finansijskih institucija, posebno Evropske investicione banke i Evropske banke za obnovu i razvoj, kako bi podržala akutne potrebe partnerskih država i njihove dugoročne potrebe vezane za društvene i ekonomske posledice. Prvi paket rešenja Tima Evropa primenjen je na najugroženije države u Africi, Zapadnom Balkanu, Bliskom istoku i Severnoj Africi, delovima Azije i Tihom

${ }^{18}$ Delegacija EU u Srbiji, Globalni odgovor EU u borbi protiv pandemije COVID-19 - Preko 15 milijardi evra za partnere i susedne zemlje, Delegacija EU u Srbiji, 8.4.2020. Internet: http://europa.rs/globalni-odgovor-eu-u-borbi-protiv-pandemije-covid-19-preko-15milijardi-evra-za-partnere-i-susedsne-zemlje/, 05/02/2021.

19 "Joint communication to the Euopean Parliament, the Council, the European Economic and Social Committee and the Committee of the Regions: Communication on the Global EU response to COVID-19", European Commission and High Representative of the Union for Foreign Affairs and Security Policy, 8 April 2020, EUR-Lex doc. JOIN(2020) 11 final, p. 1. 
okeanu, Latinskoj Americi i Karibima. Odgovor EU obuhvata usredsređenost na najugroženije kategorije ljudi, uključujući migrante, izbeglice, interno raseljena lica i njihove zajednice i integrisanje strateških ciljeva utvrđenih u Zelenom sporazumu i Digitalnoj agendi. ${ }^{20}$

Globalni paket odgovora EU, u praksi, obuhvata tri aspekta:

(1) Akcije hitne pomoći, kroz koje su sredstva usmerena na, između ostalog:

- podršku planovima za reagovanje SZO, UN i organizaciji Crvenog krsta i Crvenog polumeseca u državama sa neodgovarajućim zdravstvenim sistemima;

- humanitarnu podršku pogođenim državama;

- podršku povećanoj proizvodnji sredstava lične zaštite i medicinskih sredstava u Evropi;

- isporuke robne pomoći pogođenim državama kroz Mehanizam civilne zaštite EU;

- pružanje garancija i likvidnosti lokalnim bankama;

- podršku globalnim naporima protiv izvoznih ograničenja i obezbeđivanju nesmetanih lanaca snabdevanja, posebno za osnovna medicinska sredstva i lekove;

- povezivanje Zapadnog Balkana sa inicijativama EU, poput one o zajedničkoj nabavci medicinske opreme, za brzo upozoravanje na zarazne bolesti. ${ }^{21}$

(2) Podršku istraživanjima, zdravlju i sistemima vode, finansiranjem, između ostalog:

- podrške partnerskim državama u izgradnji sistema zdravstvene i socijalne zaštite;

- podrške naporima u komunikaciji i podizanju svesti o merama zaštite i o higijeni kako bi se sprečilo širenje zaraze;

- omogućavanje korišćenja sredstava EU za globalne zdravstvene inicijative;

- podrške istraživanjima dijagnostike, lečenja i prevencije i kada vakcina bude dostupna, brzom odobravanju i subvencionisanju vakcina i isporuke ugroženim državama;

\footnotetext{
${ }^{20}$ Ibid., pp. 2-4.

${ }^{21}$ Ibid., para. II 1.1.
} 
- podrške obuci stručnjaka, epidemiološkom nadzoru i jačanju regionalnih zdravstvenih organizacija u Africi, Latinskoj Americi i Karibima, Aziji i Tihom okeanu;

- dobrodošlicu državama kandidatima na Zapadnom Balkanu u Odbor za zdravstvenu bezbednost EU uz najbolje povezivanje potencijalnih kandidata;

- podrške jednakom pristupu zdravstvenim sistemima za migrante i lokalne zajednice. ${ }^{22}$

(3) Rešavanje ekonomskih i društvenih posledica, plasiranjem sredstava za, između ostalog:

- direktnu budžetsku podršku i koncesiono finansiranje partnerskim državama za reforme socijalno-ekonomskog razvoja i smanjenje siromaštva i zaštitu radnika tokom krize;

- mobilizaciju makrofinansijske pomoći za Zapadni Balkan i države susedstva;

- podršku privatnom sektoru, posebno malim i srednjim preduzećima i samozaposlenim, putem garancija, podrške likvidnosti i tehničke pomoći i preusmeravanju garancija iz Evropskog fonda za održivi razvoj na kratkoročnu podelu rizika na zajmove;

- kredite Evropske investicione banke javnom sektoru, pre svega za medicinsku opremu;

- izgradnju, sa međunarodnim organizacijama i evropskim kompanijama, otpornih lanaca strateškim sektorima i obezbeđivanju radnih prava i društvene odgovornosti preduzeća;

- unapređivanje načina pomoći kod dugovanja za pogođene zemlje koje razmatra MMF. ${ }^{23}$

Evropska komisija je, u novembru 2020. godine, predložila Evropskom parlamentu i vladama država članica listu aktivnosti kao odgovor na pandemiju Kovid 19. Predložene aktivnosti obuhvataju nadgradnju Evropskog centra za sprečavanje i kontrolu bolesti kako bi se unapredio nadzor nad bolestima i kapacitet da pomogne državama članicama da se pripreme i odgovore na epidemije, uključujući mreže referentnih laboratorija za ljudske patogene. Takođe je predloženo novo telo, služba EU za pripravnost i reagovanje u vanrednim

\footnotetext{
22 Ibid., para. II 1.2.

${ }^{23}$ Ibid., para. II 1.3.
} 
situacijama u zdravstvu, čiji bi jedan od zadataka bilo usmeravanje finansiranja kompanijama i univerzitetima koji razvijaju lekove i vakcine. ${ }^{24}$ Istovremeno, savetnici Evropske komisije za nauku i etiku objavili su izveštaj „Unapređenje pripravnosti i upravljanja pandemijom", u kome se predstavlja ključna literatura o nizu tema, uključujući biologiju, širenju i ekonomskim dejstvima zaraznih bolesti; najugroženijim populacijama; kao i o "porastu dezinformacija". Cilj izveštaja je da bude jedinstvena baza informacija zaduženima za usklađivanje planova odgovora na pandemiju u državama članicama.

Plan EU protiv krize Kovid 19, sa aspekta odgovornosti za planiranje i odgovor, ima suštinski funkcionalni problem. Naime, države članice EU se nisu suočile sa izazovom koji je zahtevao toliko koordiniran odgovor u oblasti javnog zdravlja kao pandemija Kovid 19. Budući da je zdravstvena zaštita u nadležnosti država, EU nema kapacitet odlučivanja na visokom nivou kako bi se mogla brzo mobilisati, bilo jačanjem svog Odbora za zdravstvenu bezbednost (postojećeg tela EU za koordinaciju u zdravstvu) ili stvaranjem mreže višeg nivoa koja bi se mogla aktivirati u slučaju vanredne zdravstvene situacije. U početku pandemije neke države EU obustavile su izvoz zaštitne opreme čak i u druge države članice. EU i države članice su alocirale fondove za podršku odgovoru, ali članice još uvek nemaju zajednički osnov intervencije, tako da se razlikuju u primeni mera u ključnim segmentima odgovora, poput sadržine socijalne distance ili pravila karantina. U tom smislu, u poređenju sa drugim prekograničnim pitanjima, poput zagađivanja, odgovor EU na pandemiju deluje provizoran.

\section{Odlike nacionalnih akcija protiv pandemije}

Upravljanje u pandemiji zahteva saradnju između nacionalnih izvršnih vlasti, zdravstvenih uprava, javnih zdravstvenih ustanova i SZO. Da bi se obezbedilo stručno učešće u donošenju odluka i praćenju krize javnog zdravlja, neke države imaju stalna tela, a druge za te svrhe predviđaju različite oblike kolektivnih tela. Glavnu ulogu u početnoj reakciji imaju nacionalne institucije, pre svega bolnice. Okvir za nacionalno delovanje utvrđen je u IHR, koji jeste pravno obavezujući

\footnotetext{
${ }^{24}$ The European Council, Video conference of the members of the European Council, European Council, 19 November 2020. Internet https://www.consilium.europa.eu/en/ meetings/european-council/2020/11/19/, 05/02/2021.
} 
ali bez mehanizma izvršenja. Upravljanje pandemijom oslanja se i na unutrašnje mehanizme koji obezbeđuju standarde odgovornosti, kontrolu korupcije i vladavinu prava. Inače, u stručnim analizama primećuje se da mnoge države ispoljavaju lošije standarde upravljanja i viši nivo korupcije političkih i ekonomskih elita. ${ }^{25}$

Budući da je pandemija Kovid 19 stvorila pretnju za javno zdravlje i za društvenu i ekonomsku stabilnost, inicijalno nacionalno upravljanje pandemijskom krizom, bez pouzdano delotvorne vakcine protiv SARS-KoV 2 ili utvrđene terapije za Kovid 19, bilo je usmereno na dve dimenzije: s jedne strane, na sposobnost masovnog testiranja, stopu širenja zaraze, medicinske protokole za zaražene sa teškim simptomima itd. a, s druge strane, na aspekt održavanja ekonomije i osnovnih usluga. Još uvek je nemoguće pouzdano proceniti efikasnost i delotvornost pojedinih upravljačkih modela, ali činjenica sve učestalijih protesta protiv nekih mera, pre svega zaključavanja, ukazuje na postojanje nedostatka poverenja bar dela stanovništva u odluke.

Pandemija je izazvala globalni društveno-ekonomski potres. Iz tog razloga, na donošenje odluka nužno su uticali ekonomski interesi. U zavisnosti od nivoa ovog uticaja, mere protiv pandemije razlikovale su se u primeni blokada, otvaranju zbog ekonomskih razloga i merama podrške, koje su obrazlagane nepovezanom argumentacijom o trenutnom dejstvu virusa.

Početak pandemije obeležio je šokantan pad tražnje i cena fosilnih goriva i minerala, kao i posledice preraspodele proizvodnje na globalizovanom tržištu, što je za posledicu imalo nedostatak dostupnosti zaštitnih maski za stanovništvo i respiratora za pacijente sa teškim simptomima. Institucionalni odgovor je, po pravilu, podložan kompromisu sa interesima političke i ekonomske elite. ${ }^{26}$ Ono što predstavlja problem sa aspekta nacionalnog odgovora je mogućnost da moćna elita utiče na odluke i pravila, a bez obzira na interes javnog dobra. Ovo prevazilazi administrativnu korupciju, zato što generiše rizik od „zarobljavanja države“ u formulisanju zakona, propisa i politika. ${ }^{27}$ Korišćenje pandemijske

\footnotetext{
${ }^{25}$ Alan Shipman, June Edmunds \& Bryan Turner, The New Power Elite: Inequality, Politics and Greed, Anthem Press, London/New York, 2018, p. 68.

${ }^{26}$ Terry Moe, Vested Interests and Political Institutions, Political Science Quarterly, vol. 130, no. 2, 2015, p. 284.

27 Daniel Kaufmann, What the Pandemic Reveals about Governance, State Capture, and Natural Resources, Brookings Institution, July 10, 2020.
} 
situacije za korist ekonomskih i političkih interesa uspostavljenih pre pandemije ugrožava poverenje javnosti.

Mere suočavanja sa pandemijom morale su biti preduzete u situaciji koja je vanredna, u smislu da je zahtevala viši stepen gotovosti i angažovanja subjekata sistema. Stoga su bile prepuštene izvršnoj vlasti, a politike su, umesto predstavničkih tela, predlagala i usvajala anonimna stručna tela ili timovi. Posledica toga je nedostatak transparentnosti i, zbog toga, skepticizam javnosti u pogledu efikasnosti i pravičnosti mera u pogledu glavnog cilja - jačanja odgovora zdravstvenog sektora na pandemijsku bolest.

Početni odgovor na pandemiju Kovid 19 takođe je odlikovalo svakodnevno usvajanje hitnih naredbi i odluka. Ovi podzakonski akti bili su praćeni sankcionisanjem građana, preduzeća i mesta okupljanja (pre svega verskih) zbog činjenja koje je do tada bilo ustaljeno. Ti akti su javno promovisani sloganima o potrebi „zajedništva“ (pred zajedničkom pretnjom) i „izravnavanja krive“ (širenja zaraze), međutim u odnosu na stanje pre pandemije bitna razlika se ogledala u nedostataku rasprave u javnom prostoru, odnosno institucionalne opozicije, odgovarajućeg postupka donošenja odluka, kao i odlučivanje zasnovano na pretpostavci da izvršna vlast i zdravstvena birokratija "čuvaju bezbednost ljudi“ i „spasavaju živote“. Administriranje krize u zajedničkom interesu samo se u početku zasnivalo na postojećim zakonima. Ubrzo su usvajane nove mere, koje su obrazlagane interesom javne sigurnosti. Rizik ovakvog razvoja je stvaranje situacije u kojoj se suprotstavljanje sadržini mera osuđuje kao bezobzirno, naivno, nemarno za ljudski život, jer sumnja u „stručnjake“. Prateća posledica je da se sredstva informisanja, po pravilu, nekritički svrstavaju uz izvršnu vlast u širenju straha (i posredno, u podsticanju nepreispitivanja vlasti).

Da bi se pod kontrolom održala dejstva virusa za koji nije bilo vakcine ili terapije, u praksi je inicijalno bio primenjen sistem za suočavanje sa egzistencijalnim pretnjama i plasirane su informacije. U okviru tog mehanizma, javnost je bila podvrgnuta stalnom ponavljanju da se mora neprestano plašiti infekcije SARS-KoV 2. Posredni rezultat toga je podsticanje poslušnosti i širenje osnovne poruke u podlozi da zbog opasne pandemije nije pogodan trenutak za političku raspravu, pa čak ni za poštovanje odgovarajućeg institucionalnog postupanja u odlučivanju.

Internet: https://www.brookings. edu/blog/future-development/2020/07/10/what-thepandemic-reveals-about-governance-state-capture-and-natural-resources/, (05.02.2021) 


\section{Normativni problem u nacionalnim reakcijama na pandemiju}

Pandemija Kovid 19 nametnula je potrebu da ljudi promene svoje navike i da čak prihvate ograničenja slobode kretanja i okupljanja, u interesu opšteg dobra. Kako širenje virusa predstavlja vanredno stanje, ono generiše izazove za ljudska prava i slobode. Otuda su administrativni ciljevi bili suočeni sa potrebom prevazilaženja različitih i složenih prepreka.

Većina nacionalnih i lokalnih vlasti primenile su mere za uticaj na ponašanje u cilju izbegavanja društvenih kontakata, tj. socijalnog distanciranja. Ovo, normativno posmatrano, predstavlja usmeravanje kolektivne akcije na mikro nivou, s ciljem da se obezbedi javno dobro. Prihvatanje takvog normativnog pristupa zavisi od individualne procene da li se javno dobro može uživati uz težnje ličnim interesima (izaći, družiti se) ili da njegovo uživanje zahteva prihvatanje mera u zajedničkom interesu. To ukazuje da činilac pristupa suočavanja sa pandemijskom krizom kroz kolektivne akcije na mikro nivou predstavljaju ustaljene društvene norme. $U$ tom smislu, zajednice u kojima je standard ponašanja neposredan fizički kontakt zahtevaju veći svesni napor da se sprovede socijalno distanciranje od onih u kojima društvena interakcija uključuje manje fizičkog kontakta. Stoga, upravljanje krizama u zaštiti javnog dobra trebalo bi da poštuje društvene navike i načine ponašanja. Da bi se prevazišle, važne su društvene veze koje doprinose nivou poverenja u odluke i donosioce odluka, a posebno u proces odlučivanja.

Globalizacija generiše niz problema koji prevazilaze nacionalne granice. Na međunarodnom nivou, međutim, još uvek nema demokratskih institucija koje bi se tim problemima mogle baviti legitimno. Opšta dobra i oblasti u kojima višedimenzionalnost problema zahteva usaglašenu globalnu politiku su mir, međunarodna bezbednost, bolesti, finansijska stabilnost, trgovina, znanje. $U$ ovim oblastima države su prenele određena ovlašćenja institucijama unutar sistema UN. ${ }^{28}$ Racionalan odgovor na pandemiju SARS-KoV 2 obuhvatao je svest o ranjivosti na globalnu pretnju i potrebu za zajedničkim odgovorima. Stoga bi nacionalno administriranje u zaštiti javnog zdravlja kao opšteg dobra nužno trebalo da obuhvati šira predviđanja. Pored toga, činjenica da doprinos javnom zdravlju u slučaju pandemije u suštini doprinosi sopstvenoj bezbednosti postaje

\footnotetext{
${ }^{28}$ Dragan Đurđević \& Miroslav Stevanović, Value Problem in Perception of Sustainable Development in International Public Law, Progress in Economic Sciences, no. 4, 2017, pp. 196-197.
} 
deo javnog diskursa, čega bi sastavni deo trebalo da bude svest o pravu da se donosioci odluka pozivaju na odgovornost za svoje propuste. Dalje, SARS-KoV 2 zaražava globalno, što postavlja dilemu oko delotvornosti rešenja zasnovanih na izolacionističkom pristupu. Konačno, pandemija je istakla značaj nauke i dokaza u političkom odlučivanju. Ovi elementi, koji zahtevaju promenu svesti ljudi, otvaraju prostor za osnaživanje njihovog položaja u procesu odlučivanja.

Pandemija je stvorila priliku da se unapredi delotvornost i efikasnost odgovora na krizu bezbednosti javnog zdravlja i, posredno, da se unapredi svest o zaštiti javnih dobara. Izazov za te vrednosti predstavlja izazov za vrednost opšteg dobra. Potcenjivanje opšteg dobra, kako ukazuje analiza pokretača i otpornosti korupcije, je činilac podsticaja korupcije. ${ }^{29}$ Ukoliko donošenje odluka dođe pod uticaj korupcije, vrednost javne sfere je pod rizikom da bude zarobljena, što posledično smanjuje sposobnost dobrog upravljanja.

Strah zbog posledica Kovid 19 pokrenula je proces u kojem vlasti donose podzakonske akte bez institucionalne rasprave i odgovarajućeg postupka, praćene skrajnjivanjem i ignorisanjem pokušaja da se kontroliše moć birokratije. Imajući u vidu razvoj događaja nakon terorističkog napada u Njujorku u septembru 2001. godine (9/11), da nakon devetnaest godina nema pokretanja institucionalne rasprave da li su mere učinile ljude bezbednijim, dok administracija nastavlja trend da postaje veća, skuplja i sve manje ograničena zakonima i ustavom, trebalo bi imati na umu da je za oporavak društva nakon stanja kolektivnog straha potrebno vreme. Suštinski problem je u tome što nametnuta ograničenja u nekim slučajevima mogu kršiti ustavna prava i građanske slobode ličnosti. Nije sporno da uvođenje privremenih ograničenja nekih prava može biti razumno radi zaštite javnog zdravlja, ali ona ne bi trebalo da postanu prekomerno opterećenje koje se uvodi diskreciono.

\section{Vrednosni problem u nacionalnim reakcijama na pandemiju}

Pristup zasnovan na pretpostavci da političari i zdravstvene birokrate „čuvaju sigurnost ljudi“ i „spasavaju živote“, vrednosno posmatrano, podseća na reakciju

\footnotetext{
${ }^{29}$ Claudia Baez Camargo, Rethinking Governance in the Times of the COVID 19 Pandemic, Basel Institute on Governance, July 10, 2020. Internet: https://baselgovernance.org/ blog/rethinking-governance-times-Kovid19-pandemic, 05/02/2021.
} 
nakon 9/11, kada je javnost usmeravana da prihvati odgovor podzakonskim aktima u ime zajedničke „sigurnosti“. Oba modela odlikuje pristup da se zasnivaju na promociji straha i poverenja u stručnjake bez preispitivanja i odgovarajuće procedure. U tom kontekstu, posebna analogija sa reakcijom posle 9/11 je da je stručne tvrdnje iznosila obaveštajna zajednica (institucionalni stručnjaci) koja je širila diskurs o proizvodnji „oružja za masovno uništenje“ u Iraku, što nikada nije potvrđeno i uglavnom se ispostavilo kao insinuacije i/ili laži. U slučaju odgovora na pandemiju Kovid 19 mnogi stručnjaci postavljaju pitanja koja se kreću od smrtnosti same bolesti do efikasnosti obaveznih maski i zaključavanja protiv virusa. Pozivanje na „tvrdnju stručnjaka“ bez institucionalne rasprave, stoga, nosi rizik birokratske arbitrarnosti iznad naučne istine. Upravljanje $u$ pandemiji je pokrenulo trend verovanja koje se oslanja na stručnjake koji posredno promovišu moć izvršne vlasti. Da bi se podstaklo nekritičko prihvatanje takvog diskursa, javnost se uporno zasipa sloganima. Strah od Kovid 19 i podrška administrativnim merama oslanjali su se na poruke u sloganima, poput „svi smo u ovome zajedno", „ispravimo krivu“, "\#ostanikuci“..., od kojih neke insinuiraju neposlušnost kao pretnju ili nagoveštavaju da poslušnost objavama nije stvar izbora. Razlika između upotrebe krilatica nakon 9/11 i današnjih slogana može se pripisati društvenim mrežama koje olakšavaju širenje poruka. Postavljanjem konteksta porukama se oblikuje narativ, koji nastoji da uspostavi društveno pamćenje iz kojeg proističe prihvatljivost ili podložnost samo određenim informacijama. Na taj način se posredno uspostavlja narativna struktura društvenog identiteta. Vrednosni aspekt takvog identiteta, odnosno pitanje pravde i morala, podstiče se tako što se podržava određeni skup uverenja i, posebno, stvaraju narativi koji mogu biti polemični, ali nisu argumenti s ciljem neposrednog dokazivanja tih verovanja. $U$ tom obrascu uticaja, funkcija poruka se praktično svodi na nametanje konteksta. Takvu funkcionalizaciju poruka, posebno u sajber prostoru, gotovo je nemoguće empirijski potvrditi, a njihova uloga se može utvrditi samo iz opštijeg konteksta. Upotreba fraza funkcioniše i da signalizira poželjno, odnosno nosi osnovnu poruku u podlozi da se podržava „nova normalnost" koja se proklamuje izvan redovnog institucionalnog procesa odlučivanja. Glavni praktični problem upravljanja vezan je za transparentnost i odgovornost. U upravljanju krizom u slučaju pandemije Kovid 19, a posebno u početnoj fazi, čini se da se ove komponente demokratskog odlučivanja potiskuju kroz uspostavljanje prihvatljivosti ili podložnosti stanovništva određenim informacijama, odnosno razvijanjem stereotipa i predrasuda. Posledica je 
nedostatak pritiska ili interesa za institucionalnu raspravu, što uzrokuje strukturalni problem vezan za poverenje u racionalnost i utemeljenost odluka.

Strukturalni problem vezan za racionalnost i proceduralnu zasnovanost odluka posebno je značajan ako se ima u vidu domašaj korporativne kontrole nad tehnološkom strukturom sajber prostora. Naime, tehnološke korporacije su u poziciji da usmeravaju korisnike društvenih mreža kojima upravljaju, bez ikakve demokratske kontrole, što mogućnost njihovog uticaja na racionalnost odluka čini objektivnim rizikom. S tim u vezi, ove korporacije imaju mogućnost da vrše indirektni uticaj, potenciranjem pozitivnih ili negativnih emocija o nekoj temi, kao i podsticanjem podložnosti određenim emocijama među učesnicima na mreži. Ako je u demokratskom procesu važna uloga procedura radi omogućavanje sučeljavanja različitih mišljenja i interesa, ne treba potceniti da potenciranjem slogana i izgradnjom afiniteta korporacije koje kontrolišu infrastrukturu na internetu uživaju netransparentnu prednost. ${ }^{30} \mathrm{Na}$ primer, tokom karantina raste oslanjanje na internet komunikacije i time uticaj tih korporacija, iz čega proizilazi da je njihov poslovni interes povezan sa tom merom, te bi njihovo racionalno ponašanje bilo da podstiču emocije koje bi ljude otvarale za njenu primenu. Čak i pre pandemije Kovid 19, u doktrini je identifikovan strukturni potencijal korporativnih subjekata za oblikovanje narativa u sajber prostoru kao izazov za demokratske procese i slobode u društvu. Ovaj izazov je, najopštije posmatrano, vezan za situacije kada zavisnost od tehnologije dostigne nivo van demokratske kontrole, pre svega pravno, što otvara mogućnost za netransparentni uticaj na opštu atmosferu na društvenom, pa čak i privatnom nivou.

Drugi praktični problem tiče se suočavanja sa izazovima prekogranične prirode, budući da još uvek ne postoje demokratske institucije koje bi se bavile transnacionalnim problemima. To je u slučaju pandemije, kada mnoga pitanja zahtevaju kolektivna rešenja, rezultiralo nacionalnim odlukama zasnovanim na međunarodnom sistemu, bez odgovarajuće procedure.

Stavljanje bezbednosti individue $u$ međunarodnu agendu, kroz međunarodne standarde ljudskih prava i vladavinu prava, dovelo je do razvoja

\footnotetext{
${ }^{30}$ Miroslav Stevanović \& Dragan Đurđević, The Challenges of Shaping Narratives in Cyber Space for National Security, in: Vladimir Marinković et al. (eds.), Freedom and Security in Real and Cyber Space: Thematic Proceedings International Scientific Conference Held on June 8, 2018, Belgrade, Serbia, Higher Educational Institution for Applied Studies of Enterprenuership, Belgrade, 2019, p. 232.
} 
koncepta ljudske bezbednosti. Ovaj normativni koncept prihvaćen je u okviru napora na izgradnji „globalnog društva“. Njegov izraz je konstrukt odgovornosti međunarodne zajednice za zaštitu osnovnih ljudskih prava, uključujući i za aspekte održivog razvoja. ${ }^{31}$ Karakter odgovora u pandemiji ima sličnosti sa upravljanjem na polju održivog razvoja, u pogledu racionalnih odluka koje se tiču životne sredine, odnosno u zajedničkom interesu. U slučaju poslova vezanih za životnu sredinu, šire globalne međuzavisnosti dovode do povećanja bezbednosnih izazova za širi spektar društvenih grupa i, povratno, održivi razvoj kao globalno opšte dobro, te trpi uticaj globalizovane bezbednosti. Suočavajući se sa ovim izazovima, mehanizmi održivog razvoja uključuju oslanjanje na dva koncepta: ljudske bezbednosti i zajedničke odgovornosti država. Budući da su ovi koncepti razvijeni za zaštitu opšteg dobra, oni bi trebalo da budu primenljivi u slučaju pandemije. Na primer, zajednička odgovornost u pitanjima zaštite životne sredine, koja je potvrđena u mnogim međunarodnim ugovorima, zasniva se na tome da su dobra iz životne sredine - ekonomski resurs nacija, dobro čovečanstva, poželjno stanište ili opšta briga svih država. Čini se da se javno zdravlje država uklapa u te kriterijume, te da bi pravni koncept zajedničkog interesa bio primenjiv na situaciju kada virus napada svetsku populaciju.

Pravni interes države za javno zdravlje, kao dobro od zajedničkog interesa, može se ogledati u zahtevu za pravičnim pristupom i korišćenjem dostupnih resursa za istraživanje, lečenje, informisanje i odgovornost za sprečavanje štete. U slučaju zajedničke pretnje javnom zdravlju, države sprovode nacionalne politike, ali pravila SZO ne predviđaju njihovu dužnost da uzmu u obzir potrebe ostalih država. Kao što je pokazala pandemija, problem predstavlja raspoređivanje resursa, koji se uglavnom obezbeđuju na nivou humanitarne pomoći. Artikulacija ovog normativnog pristupa zavisi od prepoznavanja globalnog javnog zdravlja kao globalne nestabilnosti. Posle skoro godinu dana pandemije, bez izvesnog rešenja, čini se razumnim razmišljati o normativnom uokviravanju brige za javno zdravlje. Budući da bi ovo potencijalno ograničilo diskreciono delovanje razvijenih država, nije realno očekivati saglasnost o

\footnotetext{
${ }^{31}$ Miroslav Stevanović \& Dragan Đurđević, Globalisation as a Factor of Normative Content of Sustainable Development in International Public Law, in: Knežević Saša, Nastić Maja (eds), Globalisation and Law: Collection of papers from the International Scientific Conference Held on 20-21 April 2017, Nišs, Serbia, Faculty of Law University of Niš, Niš, 2017, p. 2.
} 
obavezujućim međunarodnim pravilima $u$ tom pogledu, ali je nesporno potreban komunitarniji pristup, van okvira formalne saradnje preko SZO.

Pravno posmatrano, u slučaju globalnog zdravstvenog rizika, čine se primenljiva dva načela prava životne sredine. Neizvesnost oko izvora SARS-KoV2, da li se radi o prirodnoj ili veštačkoj mutaciji, nameće problem vezano za potencijalna dejstva različitih, i često tajnih, naučnih eksperimenata, novih tehnologija i praksi. Iz ovoga proizlazi primenljivost načela predostrožnosti. Sadržaj i status ovog načela u međunarodnom javnom pravu nisu sasvim precizni, ali nesumnjivo obuhvata unapred dužnost razmatranja potencijalnih rizika. Imajući u vidu da je tokom pandemije došlo do problema distribucije neophodnih dobara poput maski i respiratora, još jedno primenljivo načelo prava životne sredine je zajednička, ali diferencirana odgovornost. Državama se, naime, ne može prepustiti da se same nose sa pretnjom koja ima pandemijski potencijal. Razvijene države imaju resurse i potencijal za suočavanje sa globalnim pretnjama po zdravlje. Sve zemlje imaju odgovornost, ali suočavanje sa zajedničkom pretnjom zahteva uvažavanje posebnih potreba država u razvoju i nerazvijenih država. Ako se globalna stabilnost i ljudska bezbednost proklamuju opštim vrednostima, odgovor na pandemiju zahteva odgovornost država koje imaju naučni, organizacioni i finansijski kapacitet da ih, ne samo unapređuju, već i da su im posvećene. Ni ovo načelo još uvek nije postiglo efikasnu primenu u praksi, ali to bi se moglo prevazići definisanjem kriterijuma primene i sadržine obaveza država u okviru globalnog odgovora.

\section{Zaključak}

Očekivati idealan model upravljanja koji bi garantovao efikasne i uspešne mere protiv zaraze virusom za koji inicijalno nije bilo vakcine, niti je bila poznata terapija, nije realno. Stoga, zaključci su ograničeni na nivo oslanjanja da će upravljanje biti racionalno do optimalno mogućeg nivoa.

Rezultati ukazuju da se funkcionalni nedostaci u reakciji na krizu Kovid 19 mogu pripisati dva osnovna uzroka. $\mathrm{S}$ jedne strane, primena transnacionalnih preporuka od strane vlasti država dovodi do problema kako takve odluke da budu prihvaćene od javnosti kada njihov izvor nema transparentan demokratski legitimitet. S druge strane, pokušaj ubeđivanja građana da prihvate ograničenja svojih sloboda sa pozicija tehnokratskih ili administrativnih ovlašćenja po pravilu 
nailazi na problem poverenja javnosti. Ovi uzroci, bez obzira da li su donošene mere i odluke bile opravdane, nužno izazivaju negativne reakcije javnosti u pogledu racionalnosti odlučivanja, što vodi neefikasnosti upravljanja.

Iz pomenute uzročnosti mogu se izvesti dve specifične potrebe za dobrim upravljanjem u savremenom, informacionom dobu. Prvo, da bi se obezbedilo veće poverenje javnosti u razloge za donete odluke, ne samo za one povezane sa pandemijskim okolnostima, učesnici procesa odlučivanja trebalo bi da koriste dijagnostiku i alate zasnovane na dokazima koje je nauka razvila i odobrila. Drugo, pored transparentnosti, efikasno sprovođenje administrativnog odgovora, opet ne samo u pandemiji, nužno zahteva poverenje u one kojima je povereno zvanično arbitriranje naučne istine.

Rezultati daju osnov za tri empirijske napomene. Prva proizilazi iz iskustva sa početnim pandemijskim reakcijama, a to je potreba da se evaluira postojeći mehanizam kako se ključne globalne zdravstvene informacije generišu, procenjuju i predstavljaju donosiocima odluka. Druga empirijska lekcija proizilazi iz činjenice da se strategija nacionalne bezbednosti trenutno koristi kao okvir za saznanja, iz čega proističe potreba za rekonceptualizacijom doktrina nacionalne bezbednosti i njihovom prilagođavanju zajedničkim pretnjama. Treća praktična napomena tiče se globalnog odgovora i može se izvesti iz neefikasnosti reakcije koje je preporučila Evropska komisija. Čini se opravdano stvaranje mreže višeg nivoa, ali preporuka za stvaranje vrhovne zdravstvene mreže je izvan nadležnosti tela koja su u stvari ekvivalent državne službe i da mora da potiče od autoriteta šefova država ili vlada.

Ovaj rad je ograničen na pitanje efikasnosti odgovora, ali rezultati omogućavaju širu konceptualnu indikaciju, vezanu sa pitanje poverenja javnosti. Sposobnost savremenih uprava da ograničavaju ostvarivanje osnovnih ljudskih sloboda i prava nameće potrebu da se ustavom utvrdi postupak nadzora nad odlukama izvršne vlasti u vanrednim situacijama.

\section{Literatura}

Đurđević, Dragan \& Stevanović, Miroslav, Value Problem in Perception of Sustainable Development in International Public Law, Progress in Economic Sciences, no. 4, 2017, pp. 193-212. 
Grindle, Merilee, Going Local: Decentralization, Democratization, and the Promise of Good Governance, Princeton University Press, Princeton/Oxford, 2009.

Moe, Terry, Vested Interests and Political Institutions, Political Science Quarterly, vol. 130, no. 2, 2015, pp. 277-318.

Shipman, Alan, Edmunds, June \& Turner, Bryan, The New Power Elite: Inequality, Politics and Greed, Anthem Press, London/New York, 2018.

Stevanović, Miroslav \& Đurđević, Dragan, Globalisation as a Factor of Normative Content of Sustainable Development in International Public Law, in: Knežević Saša, Nastić Maja (eds), Globalisation and Law: Collection of papers from the International Scientific Conference Held on 20-21 April 2017, Niš, Serbia, Faculty of Law University of Niš, Niš, 2017, pp. 1-18.

Stevanović, Miroslav \& Đurđević, Dragan, The Challenges of Shaping Narratives in Cyber Space for National Security, in: Vladimir Marinković et al. (eds), Freedom and Security in Real and Cyber Space: Thematic Proceedings International Scientific Conference Held on, June 8, 2018, Belgrade, Serbia, Higher Educational Institution for Applied Studies of Enterprenuership, Belgrade, 2019, pp. 227-254.

Stevanović, Miroslav \& Đurđević, Dragan, Konceptualizacija pojma represivni režim u međunarodnom javnom pravu, Zbornik radova Pravnog fakulteta $u$ Nišu, vol. 57, no. 80, 2018, str. 101-116. 


\title{
SHORTCOMINGS IN NATIONAL SECURITY APPROACH TO THE COVID-19 PANDEMIC
}

\begin{abstract}
The SARS-COV-2 virus, for which there was no vaccine, created a risk that generated a global threat to individual and public health. In addition, the COVID19 pandemic has caused economic, social and political challenges for states. The reaction of states in facing these challenges, risks and threats was, generally, an attempt to impose individual behaviour and activate emergency measures to protect the common interest as a value. Although the aim was to protect the personal security and stability of political communities, the implementation of the measures faced significant reserves in the public. In this article, we present the analysis of the approach to countering a pandemic as a security threat and a virus as an "invisible enemy". To determine the reasons for the problems of response effectiveness due to the approach, we observed potential normative and value inconsistencies between national responsibility and the international framework in dealing with the global health phenomenon. The results show that the security approach has led to the fact that the effectiveness of measures and decisions depended more on accepting the discourse on the seriousness of the threat, and less on confidence in their purposefulness. This indicates a functional lack of the approach in the sense that it deviates from the basic principle of security protection, social acceptance of values, which, despite threats and protected values, has led to discord between decision-makers and the population. The analysis shows two causes of ineffectiveness related to the security approach to facing a pandemic: the implementation of transnational recommendations faces the problem of lack of democratic legitimacy, and reliance on persuasion without ex-ante readiness undermines public confidence in decisions.
\end{abstract}

Keywords: public good, preparedness, empowering people, global response, scientific assessment, social networks. 